\title{
COMENTARIO DEL LIBRO: HISTORIA GLOBAL DE AMÉRICA LATINA. DEL SIGLO XXI A LA INDEPENDENCIA, DE HÉCTOR PÉREZ BRIGNOLI BOOK REVIEW: HISTORIA GLOBAL DE AMÉRICA LATINA. DEL SIGLO XXI A LA INDEPENDENCIA, BY HÉCTOR PÉREZ BRIGNOLI
}

\begin{abstract}
Marco Palacios Rozo*
Palabras claves: Héctor Pérez Brignoli; reseña; América Latina; historia; historiografía.
\end{abstract}

Keywords: Héctor Pérez Brignoli; Book Review; Latin America; History; Historiography.

Héctor Pérez Brignoli ofrece una obra que combina narrativa historiográfica e investigación analítica de las humanidades y las ciencias sociales. El compromiso y el esfuerzo son encomiables. Trae la Historia global de América Latina $^{1}$ un par de mapas políticos actuales, 4 tablas estadísticas y 17 gráficos; 6 ilustraciones de la obra del pintor argentino Antonio Berni y 1 caricatura; unas 700 notas de pie de página, 1 bibliografía seleccionada y 1 índice onomástico. Recoge el legado de la extraordinaria síntesis histórica de Tulio Halperín Donghi, publicada inicialmente en 1967, revisada y ampliada en 1990. Hay, no obstante, una diferencia notable en el método expositivo. Mientras que Halperín llamó la atención de legos y expertos por la destreza y sutileza al tejer un relato unificado de historia de América Latina en el mundo colonial, postcolonial, neocolonial, junto con los zigzagueos y encrucijadas en ese gran proyecto de cerrar la brecha con el mundo occidental del que los Estados Unidos son "los nuevos

Fecha de recepción: 10/5/2019 - Fecha de aceptación: 1/7/2019

Colombiano. Doctor en Historia por la Universidad de Oxford, Reino Unido, Inglaterra. Profesor e investigador en El Colegio de México (COLMEX), México. Correo electrónico: mpalacios@colmex.mx

1 Héctor Pérez Brignoli, Historia global de América Latina. Del siglo XXI a la Independencia (Madrid, España: Alianza Editorial, 2018). 
señores", Pérez Brignoli fragmenta la historia conjunta y, en secciones decisivas, narra desde puntos de perspectiva estrictamente nacionales, amén de que trastoca la cronología convencional, como advierte el lector en el título.

Si Halperín plantea su historia con base en la economía, las finanzas públicas, las relaciones que emergen del proceso social, mientras que la vida política germinaba pausadamente hasta madurar a comienzos del siglo pasado, Pérez Brignoli escoge el camino de la especialización temática. Así, tenemos un capítulo que es una historia social de las ideas, otro que se basa en la historiografía económica y política, más 3 que tratan los procesos creativos y de difusión popular de las artes plásticas académicas y la música culta del siglo XX brasilero y argentino, llenando, de paso, un vacío deliberado en la obra de Halperín, así como las imágenes y estereotipos de las borrascosas relaciones de Estados Unidos y América Latina.

Inicia Pérez Brignoli con su encuentro en 1970 con un mural de Diego Rivera, el Sueño de una tarde dominical en la Alameda Central, que, entre muchos otros elementos, le habilita dar sentido a la historia latinoamericana de los últimos 200 años. En los capítulos 1, "La desesperación de Bolívar. Las independencias en perspectiva comparada", y 7, "Globalización sin desarrollo (1980-2010)", los cuales mantienen "la narrativa historiográfica clásica", no hay sorpresas de método o estilo; refrescan y actualizan, gracias al auxilio de la bibliografía básica más reciente. En el tratamiento comparado de las independencias del capítulo $1 \mathrm{y}$ en las secciones dedicadas al sistema colonial y las reformas tanto pombalinas como borbónicas del capítulo 3 -"El cortocuito de la modernidad"-, se inclina por la historiografía económica y social en la veta de la británica de los años 60 y 70, de la que también se nutrió y a la que aportó Tulio Halperín, por demás aguzado lector de los textos medulares de la Comisión Económica para América Latina y el Caribe (CEPAL) y de los sociólogos latinoamericanos de la escuela de la dependencia. Dicha historiografía trazó un gran lienzo de las formas de integración latinoamericana a la economía mundial. Precisamente, por las estancias académicas en Alemania, que agradece el autor, en este capítulo se echan de menos reconocidos trabajos de Manfred Kossok sobre el virreinato del Río de la Plata, la Santa Alianza, el papel de Latinoamérica en el curso del capitalismo mundial y viceversa, al igual que de Michael Zeuske sobre Cuba, el Caribe y la esclavitud.

Aunque Pérez Brignoli reconoce aportes de la historiografía de cuño francés, que con François-Xavier Guerra a la cabeza floreció en la década de 1990 del siglo pasado, se nota su parquedad en la recepción del paquete revisionista que ve en 1808 la fecha clave para entender la irrupción de "la revolución de independencia", eje y raíz de "la cultura política moderna" en América Latina. La irrupción de Guerra se inscribe en la revisión historiográfica de la Revolución francesa, fuertemente politizada y sin gran fundamento empírico, emprendida 
por François Furet y Pierre Nora, aprovechando el enorme aparato publicitario alrededor del bicentenaire.

El capítulo 7, igualmente narrativo, deja otras preocupaciones, en particular la disgregación en trayectorias nacionales que probablemente suscitará críticas específicas tanto de los especialistas de cada país como de quienes trabajan el campo de "globalización y desarrollo", las cuales ofrecen renovadoras clasificaciones por grupos de países, citados por el autor: Rosemary Thorp, Bértola y Ocampo, Bulmer-Thomas.

Los capítulos del 2 al 6 problematizan grandes temas y se apartan de la historia-relato de los dos mencionados. El segundo recorre 8 utopías-ideologías latinoamericanas, empleando un enfoque de historia social de las ideas o, más precisamente, de cómo sucesivas generaciones imaginaron el futuro, visto a través del lente de pensadores, políticos y gobernantes, desde Bolívar. Quizás a este capítulo debiera incorporarse el texto, "El tiburón y las sardinas", muy breve por lo demás. En algunos apartes, el lector puede sentirse abrumado por afirmaciones como esta: "La Revolución mexicana y el Leviatán que constituye su herencia resultó ser el ejemplo más elaborado y eficaz del populismo latinoamericano del siglo XX". ${ }^{2}$ Habida cuenta de la continua reinterpretación en la historiografía y las ciencias sociales del "populismo", "la Revolución mexicana", y la "posrevolución", ¿cómo entender el significado del Leviatán, a la luz de la "guerra a las drogas"? Pero quizás la principal debilidad de este denso capítulo resida en el énfasis en las rupturas entre estas ideologías-utopías sucesivas, sin dar lugar a las fuertes continuidades subyacentes, como, por ejemplo, la larga marcha latinoamericana en la construcción de ciudadanía consagrada en los constitucionalismos modernos y que mantiene diversos grados de tensión con arraigadas prácticas coloniales clientelistas, afianzadas en la desigualdad social y étnica implantada desde la conquista española.

El capítulo 3, "El cortocircuito de la modernidad", salpicado de anotaciones sagaces sobre las trayectorias históricas de las economías latinoamericanas y los regímenes políticos a partir de la época colonial, que concentró la atención de muchos especialistas en los años cincuenta y sesenta del siglo pasado, regresa al tópico de una historia rebosante de fracasos y frustraciones. No siempre fue así. El acento pesimista repica agudamente en la "larga espera" de 1825 a 1850, en los años de la Gran Depresión, o en la "década perdida" de 1980. Valga preguntarse, entonces, si este enfoque de cortocircuitos consigue sustituir una historia internacional de las economías latinoamericanas y de los juegos imperiales en que están inmersas; de las tramas de alianzas, rupturas y combinaciones entre clases sociales, entes internacionales, grupos socioprofesionales. Es este un enfoque historiográfico que parece más pertinente cuando se trata de ilustrar la

2 Ibid., 173. 
trayectoria de largo plazo de los estados considerados síntesis del poder, organizaciones burocráticas, transitorios arreglos jurídico-institucionales.

Los capítulos dedicados a la música de Heitor Villa-Lobos y a la pintura, el collage, la escultura de Antonio Berni, dos creadores que alcanzaron un lugar prominente en las capillas vanguardistas mundiales, ilustran y analizan las articulaciones del Estado populista: en el caso de Villa-Lobos, desde adentro del varguismo o por fuera y en cierto modo enfrentando al peronismo, en el de Berni. Son capítulos ricos en textura y tonalidad; más plásticos que las utopías y cortocircuitos. Pero, de nuevo, tratándose de una Historia global de América Latina, ¿por qué no armar un relato histórico alrededor del descubrimiento del folclore nacional, del papel ideológico que los Estados nacionales pretenden imponer a la música, las artes plásticas, la literatura, el teatro; a la educación musical y artística; a cooptar las consabidas "escuelas nacionalistas"; a controlar instituciones y medios —radio, cine, televisión, revistas - que les dieron un lugar y un papel en el siglo XX? Además, ¿por qué dejar por fuera los museos y la museografía nacionalista?

La esmerada obra de Pérez Brignoli pone de presente cuán difícil resulta escribir una síntesis histórica de América Latina desde nuestro presente incierto y global, que, gracias a la tecnología, facilita a los investigadores el acceso a las fuentes, no importa en dónde se hallen en el planeta. Su texto busca "provocar, discutir, problematizar". De conseguirlo, será para el avance de la historiografía latinoamericanista y del debate público, conforme a una pregunta que asoma a fines del siglo XVIII: ¿la historia, para qué? 